\title{
ANALISIS DAN DESAIN SISTEM INFORMASI MANAJEMEN TRANSAKSI TABUNGAN PADA BANK SAMPAH TERPADU MINA SEMBADA BERBASIS WEB
}

\author{
Mahesti Rancaksari ${ }^{1}$, Sri Kusumadewi ${ }^{2}$ \\ Magister Teknik Industri, Fakultas Teknologi Industri, Universitas Islam Indonesia ${ }^{1,2)}$ \\ Jl. Kaliurang Km. 14,5 Sleman, Yogyakarta 55584 \\ E-mail:mrancaks@gmail.com ${ }^{1}$,sri.kusumadewi@uii.ac.id ${ }^{2}$
}

\begin{abstract}
At the beginning of its establishment in 2013 Integrated Waste Bank of Mina Sembada operated savings transaction manually, so that sometimes in implementation had errors in data processing. Another problem that the work in the waste bank was a social working, so there was no commission that made rarely found someone who willing as an employee in it. For that, we need a system that could minimize the number of employee who could manage all the operations of the waste bank. Therefore, the purpose of this research was to design of management information systems for savings transaction web based to facilitate employee in data filling, data searching, data processing until to the report in the form of Ledger easily and facilitate members to access savings that has been saved or prospective members who will access information about the latest news and profile of Integrated Waste Bank of Mina Sembada.The results showed that "ease of website interface was recognized" of 4.04 indicated that design of management information systems for savings transaction web based had an easy aspect of Learnability, "ease of website to operated" of 3,81 indicated that design of management information systems for savings transaction web based had an easy aspect of Efficiency, "ease of considering menu and display on the website" of 3,56indicated that design of management information systems for savings transaction web based had an easy aspect of Memorability. "ease of existing website applications easy to read" of 3,92 and "easily understandable image symbols" of 3.65 indicated that design of management information systems for savings transaction web based could be said to have minimized the Errors aspect, and the overall attribute that had an average value of 3.848 rounded to 3.85 indicated that design of management information systems for savings transaction web based had an easy aspect of Satisfaction.
\end{abstract}

Keywords: Waste Bank, Management Information Systems, Website

\section{PENDAHULUAN}

Jumlah sampah akan semakin bertambah seiring dengan laju pertumbuhan penduduk dan laju pertumbuhan ekonomi. Pengolahan sampah yang masih bergantung pada keberadaan TPA (Tempat Pembuangan Akhir) akan mengalami persoalan terbatasnya lahan dan penolakan masyarakat terhadap keberadaan TPA di sekitarnya. Penumpukan sampah atau membuangnya sembarangan akan mengakibatkan pencemaran lingkungan.

Incineration atau pembakaran sampah juga akan mencemari sektor pertanian karena mengandung logam berat. Minimalisasi sampah harus dijadikan prioritas utama dengan cara 3R yaitu: Reduce (mengurangi penggunaan), Reuse (menggunakan kembali), Recycle (mendaur ulang). Industri
- industri harus mendesain ulang produk mereka agar mudah untuk didaur ulang.

Perlu disadari bahwa orang pada umumnya malas mengumpulkan sampah kecuali ada insentif ekonominya. Bank sampah adalah alternatif solusinya. Menurut Prakoso, pengelola Bank Sampah Delima Jakarta Timur dalam Ella Syafputri (2012), Bank sampah merupakan konsep pengumpulan sampah kering dan dipilah serta memiliki manajemen layaknya perbankan tapi yang ditabung bukan uang melainkan sampah. Seperti halnya pada Bank Sampah Terpadu Mina Sembada.

Namun pada masa awal berdirinya di Tahun 2013, bank sampah tersebut menemukan kendala dalam hal transaksi tabungan yang masih dilakukan secara manual sehingga terkadang mengalami 
kesalahan dalam pengolahan data. Sistem komputerisasi diharapkan dapat meminimalisasi kesalahan tersebut, namun sumber daya manusianya kurang menguasai bidang teknologi. Permasalahan lainnya yaitu dikarenakan pekerjaan di bank sampah adalah pekerjaan sosial sehingga tidak ada imbalan apapun yang membuat minimnya petugas yang rela bekerja dibank sampah.

Dalam menghadapi tuntutan persaingan global, bank sampah harus dapat mengikuti perkembangan jaman dengan memanfaatkan teknologi seperti internet. Memberikan informasi tentang bank sampah dalam internet berarti juga telah membantu masyarakat luas dalam memahami pentingnya bank sampah untuk kemudian tergerak untuk mulai menabung dibank sampah. Untuk itu diperlukan sebuah sistem sederhana yang dapat meminimalisir jumlah petugas yang dapat mengelola seluruh kegiatan operasional bank sampah.

Karena alasan tersebut, penelitian ini bertujuan untuk mendesain sebuah sistem informasi manajemen transaksi tabungan dalam bentuk website untuk memudahkan petugas dalam pengisian data, pencarian data, pengolahan data sampai dengan laporan yang berupa Buku Besar serta memudahkan penabung untuk mengakses jumlah tabungan yang telah ditabung atau calon penabung yang akan mengakses informasi tentang profil dan berita terkini Bank Sampah Terpadu Mina Sembada. Dengan adanya pembagian hak akses juga meningkatkan keamanan dari aplikasi ini.

\section{METODE PENELITIAN}

\subsection{Prosedur Penelitian}

Metode analisis yang digunakan dalam sistem ini adalah metode analisis berarah aliran data. Menurut Ryan Al Farabi (2012), metode ini mempunyai konsep bagaimana data mengalir melalui proses - proses untuk menghasilkan suatu informasi.

Prosedur penelitian yang digunakan dalam penelitian ini yaitu :
a. Tahap Persiapan
1) Observasi Lapangan

Mengamati secara langsung di lokasi Bank Sampah Terpadu Mina Sembada, untuk mendapatkan gambaran yang aktual berkenaan dengan situasi dan kondisi serta sistem pelayanan pada bank sampah terpadu ini.

2) Pengumpulan Data Primer

Mengumpulkan data jenis barang (sampah), data harga masing - masing sampah sesuai jenisnya, data penabung, data transaksi menabung, dan data transaksi penarikan tabungan pada Bank Sampah Terpadu Mina Sembada.

3) Peneliti Sebagai Volunteer

Penulis terjun langsung sebagai petugas pada bank sampah terpadu ini untuk memperoleh gambaran mengenai proses bisnis dan sistem pelayanannya.

4) Studi Literatur

Penulis mempelajari jurnal, buku dan artikel terkait dengan permasalahan yang sedang diteliti. Dalam hal ini adalah literatur tentang sistem informasi manajemen dan bank sampah dari lokasi lain.

b. Tahap Penelitian

1) Analisis Permasalahan

Dari hasil observasi, pengumpulan data primer, terjun langsung sebagai volunteer serta studi literatur, penulis mempelajari sistem yang sedang berjalan kemudian mengidentifikasi masalah yang terdapat pada bank sampah terpadu ini.

2) Analisis Data

Penulis melakukan analisa kebutuhan sistem berdasarkan data yang telah terkumpul untuk mengetahui, menentukan, menterjemahkan permasalahan serta kebutuhan yang diperlukan dalam pemecahan masalah dan pengembangan sistem.

3) Desain / Perancangan

Penulis mempersiapkan rancang bangun implementasi yaitu menggambarkan bagaimana 
sebuah sistem itu dibentuk, berupa penggambaran, perencanaan, dan pembuatan proses bisnis yang semula manual menjadi terkomputerisasi agar lebih efektif dan efisien kepada pemrogram komputer.

\subsection{Analisis Data}

Analisis kebutuhan dalam perancangan dan pembuatan website transaksi tabungan Bank Sampah Terpadu Mina Sembada ini dibagi menjadi 5 (lima) yaitu :

\section{a. Analisis Kebutuhan Keluaran}

Keluaran atau output yang dihasilkan dari sistem informasi transaksi tabungan ini adalah :

a. Informasi mengenai profil Bank Sampah Terpadu Mina Sembada Informasi ini terdapat dalam halaman muka dari website yang berisi informasi tentang profil Bank Sampah Terpadu Mina Sembada. Halaman ini dapat diakses oleh semua orang.

b. Jumlah tabungan

Jumlah tabungan ini dapat ditemukan dalam menu Saldo dalam website yang dapat diakses oleh penabung dengan menggunakan nomor rekening dari Bank Sampah Terpadu Mina Sembada untuk mengetahui saldo tabungan masingmasing penabung.

c. Buku Besar

Proses transaksi tabungan dalam sistem ini dapat diakses dan diolah oleh petugas / admin Bank Sampah Terpadu Mina Sembada.

\section{b. Analisis Kebutuhan Informasi}

Informasi yang hendak disampaikan dalam aplikasi ini didasarkan pada kebutuhan masing - masing pengguna / user dalam sistem yaitu :

- Petugas / Admin

Pada halaman khusus petugas/admin akan tersedia informasi antara lain :
1) Menu - menu yang digunakan untuk menambah / menghapus / merubah isi konten pada halaman utama seperti: foto slideshow, profil, dan berita / informasi terkini.

2) Menu untuk menambah / menghapus data petugas / admin, data penabung, data jenis sampah, data berat sampah, data harga sampah yang berubahberubah, data pemasukan dan penarikan tabungan.

3) Laporan pada Buku Besar.

4) Saldo tabungan penabung dengan mengisi password nomor rekening penabung.

- Penabung

Pada halaman khusus penabung akan tersedia informasi antara lain :

1) Profil Bank Sampah Terpadu Mina Sembada.

2) Saldo tabungan dengan password nomor rekening penabung.

3) Menu berita / informasi terkini pada Bank Sampah Terpadu Mina Sembada.

- Calon Penabung

Pada halaman khusus calon penabung akan tersedia informasi antara lain :

1) Profil Bank Sampah Terpadu Mina Sembada.

2) Menu berita / informasi terkini pada Bank Sampah Terpadu Mina Sembada.

\section{c. Analisis Kebutuhan Masukan}

Data yang dibutuhkan untuk kebutuhan masukan :

- Bagi Petugas / Admin

Untuk foto slideshow membutuhkan data foto / gambar yang dapat diunduh maksimal sebesar $800 \mathrm{~kb}$. Untuk menu Profil dan Berita / Informasi terkini Bank Sampah Terpadu Mina Sembada membutuhkan data primer yang diambil langsung dari Bank Sampah tersebut. 
Untuk menu Profil membutuhkan juga data foto / gambar. Untuk mengisi data petugas / admin membutuhkan data nama, alamat, nomor telepon dari petugas / admin. Untuk mengisi data penabung membutuhkan data nomor rekening, NIK, nama, alamat, nomor telepon. Untuk mengisi data jenis dan harga sampah membutuhkan data nama jenis sampah, berat sampah $(\mathrm{kg})$, harga sampah, biaya jasa (\%).

Untuk mengisi data pemasukan tabungan membutuhkan data nomor rekening penabung, nomor nota / resi, nama penabung, jenis sampah, harga sampah, berat sampah (kg), jumlah sampah, biaya jasa (\%). Untuk penarikan tabungan membutuhkan data nomor rekening penabung, nomor nota / resi, nama penabung, besar tabungan yang diambil (Rp), tanggal penarikan tabungan.

- $\quad$ Bagi Penabung

Data yang dibutuhkan untuk membuka menu Saldo seperti: nomor rekening penabung sebagai password untuk masuk ke dalam sistem.

- Bagi calon penabung

Data yang dibutuhkan untuk membuka profil Bank Sampah Terpadu Mina Sembada dan berita / informasi terkini Bank Sampah Terpadu Mina Sembada dengan mengakses website yang telah tersedia.

\section{d. Analisis Kebutuhan Proses}

Analisis ini menjabarkan proses - proses bisnis yang terdapat dalam sistem. Proses proses yang terkait dengan kemampuan sistem tersebut dapat dilihat dalam proses bisnis Bank Sampah Terpadu Mina Sembada berikut ini :

- $\quad$ Proses Pada bagian pendaftaran, petugas mengisi nomor urut pendaftaran penabung, tanggal menabung, nama penabung, alamat penabung, dan nomor rekening penabung, pada kertas pendaftaran untuk diserahkan pada petugas bagian pemilahan dan penimbangan.

- Pada bagian pemilahan dan penimbangan, petugas memanggil antrian berdasar kertas pendaftaran dari bagian pendaftaran lalu melakukan pemilahan dan penimbangan sampah kemudian melaporkan hasil sampah yang ditabung menurut jenis dan beratnya pada bagian pencatatan. Jenis sampah yang ditabung di Bank Sampah Terpadu Mina Sembada antara lain adalah koran, arsip putih, duplex, kardus, botol plastik, botol air mineral, plastik warna, plastik cat / campur, kaleng, botol kaca, aluminium, logam / besi, plastik kerasan dan lain - lain. Sampah yang sudah terpilah kemudian dikumpulkan dan dikelompokkan berdasarkan jenisnya di gudang penyimpanan.

- Pada bagian pencatatan, petugas mencatat hasil penimbangan yaitu jenis dan berat sampah yang dihitung perKilogram pada lembar penerimaan dan kartu / resi penerimaan (satu lembar diserahkan pada penabung, satu lembar untuk diserahkan pada bagian pencatatan di Buku Besar).

- Pada bagian pencatatan di Buku Besar, petugas mencatat total hasil penimbangan berdasarkan lembar penerimaan dari bagian pencatatan, mencatat pengambilan tabungan, juga besarnya tabungan setelah dikurangi biaya operasional untuk nantinya sebagai pedoman dalam menjual sampah terpilah kepada pengepul yang didatangkan setiap beberapa bulan sekali.

- Hasil tabungan dicatat oleh bagian pencatatan di Buku Tabungan berdasarkan dari Buku Besar. Hasil tabungan selama beberapa bulan tersebut dapat diambil langsung maupun disimpan tergantung permintaan dari penabung. 


\section{e. Analisis Kebutuhan Antarmuka}

Kebutuhan antarmuka dalam sistem informasi transaksi tabungan ini yaitu :

- LOGIN: field Username untuk memilih nama pengguna, field Password untuk memasukkan kode, tombol Login untuk masuk kedalam sistem.

- Menu Slideshow : tombol Browse untuk menambah / merubah foto / gambar yang masing - masing maksimal berukuran $800 \mathrm{~kb}$, tombol Simpan untuk meng-upload foto / gambar ke halaman utama, tombol $\mathrm{x}$ untuk menghapus foto / gambar.

- Menu Profil : tombol EDIT PROFIL untuk mengedit profil, tombol $\mathrm{x}$ untuk menghapus foto / gambar diprofil, tombol Browse untuk mengunduh foto / gambar diprofil, field Isi untuk menambah / merubah / menghapus isi konten profil, tombol Simpan untuk meng-upload ke halaman Profil, tombol Batal untuk membatalkan penyimpanan.

- Menu Berita / Informasi : field Search untuk entry pencarian, tombol + untuk menambah berita / informasi, field Judul untuk entry judul berita/informasi, field Isi untuk entry isi konten berita / informasi, tombol Browse untuk mengunduh foto / gambar di berita / informasi, tombol Simpan untuk mengupload ke halaman Berita / Informasi, tombol Batal untuk membatalkan penyimpanan, tombol - untuk merubah berita / informasi, tombol 9 untuk menghapus berita / informasi, field halaman untuk entry halaman, tombol Go untuk menuju ke halaman yang dicari, tombol First untuk menuju ke data yang paling awal, tombol Previous untuk menuju ke data sebelumnya, tombol Next untuk menuju ke data selanjutnya, tombol Last untuk menuju ke data yang paling akhir.

- Menu Data Petugas : field Search untuk entry pencarian, tombol + untuk menginput / menambah data petugas / admin, field Username untuk entry nama pengguna, field Nama untuk entry nama petugas / admin, field Alamat untuk entry alamat petugas / admin, field Telepon untuk entry nomor telepon petugas / admin, tombol Admin untuk entry akses Admin, tombol Petugas untuk entry akses petugas, field Password untuk entry kode, tombol Simpan untuk menyimpan data, tombol Batal untuk membatalkan penyimpanan, tombol untuk merubah data,tombol 9 untuk menghapus data.

- Menu Data Anggota : field Search untuk entry pencarian, tombol + untuk menginput / menambah data penabung, field No. Rekening untuk entry nomor rekening penabung, field NIK untuk entry NIK penabung, field Nama untuk entry nama penabung, field Alamat untuk entry alamat penabung, field Telepon untuk entry nomor telepon penabung, field Telepon untuk entrynomor telepon penabung, tombol Simpan untuk menyimpan data, tombol Kembali untuk membatalkan penyimpanan, tombol - untuk merubah data,tombol $\mathcal{H}_{\text {untuk menghapus data, }}$ field halaman untuk entry halaman, tombol Go untuk menuju ke halaman yang dicari, tombol First untuk menuju data yang paling awal, tombol Previous untuk menuju ke data sebelumnya, tombol Next untuk menuju ke data selanjutnya, tombol Last untuk menuju ke data yang paling akhir.

- Menu Data Jenis Sampah: field Search untuk entry pencarian, tombol + untuk meng-input / menambah data jenis sampah, field Jenis Sampah untuk entry nama jenis sampah, field Satuan untuk entry berat sampah dalam $\mathrm{kg}$, field Harga (Rp.) untuk entry harga satuan sampah, field Jasa untuk entry persen biaya operasional, tombol Simpan untuk menyimpan data, tombol Batal untuk membatalkan penyimpanan, tombol. untuk merubah data,tombol $\mathcal{Y}_{\text {untuk }}$ menghapus data, field halaman untuk entry halaman, tombol Go untuk menuju ke halaman yang dicari, tombol First 
untuk menuju ke data yang paling awal, tombol Previous untuk menuju ke data sebelumnya, tombol Next untuk menuju ke data selanjutnya, tombol Last untuk menuju ke data yang paling akhir.

- Menu Saldo Awal : tombol + untuk menambah meng-input / menambah penabung yang akan dimasukkan saldo awal, field Search untuk entry pencarian, tombol - untuk merubah data, tombol 9 untuk menghapus data, field halaman untuk entry halaman, tombol Go untuk menuju ke halaman yang dicari, tombol First untuk menuju ke data yang paling awal, tombol Previous untuk menuju ke data sebelumnya, tombol Next untuk menuju ke data selanjutnya, tombol Last untuk menuju ke data yang paling akhir, field Nama Anggota untuk entry nama penabung dengan menggunakan scroll pilihan, field Saldo (Rp.) untuk menginput jumlah saldo awal yang akan dimasukkan, field Tanggal untuk entry tanggal pemasukkan saldo awal dengan menggunakan scroll pilihan, tombol Simpan untuk menyimpan data, tombol Batal untuk membatalkan penyimpanan.

- Menu Transaksi Penyimpanan: field Masukkan No. Rekening untuk entry pencarian dengan menggunakan nomor rekening penabung, tombol Search untukmencari data nama penabung dan jumlah saldo tabungan, tombol Input Tabungan untuk meng-input penyimpanan / pemasukan tabungan, field Nota untuk entry kode nota / resi, field Nama untuk entry nama penabung dengan menggunakan scroll pilihan, field Jenis Sampah untuk entry nama jenis sampah dengan menggunakan scroll pilihan, field harga (Rp) untuk entry harga sampah, field per untuk entry satuan berat $(\mathrm{kg})$, field Jumlah untuk entry jumlah sampah, field Total (Rp) untuk jumlah total tabungan, field Jasa (Rp) untuk besar biaya operasional, field Tanggal untuk entry tanggal menabung, tombol Simpan untuk menyimpan data, tombol Kembali untuk melihat hasil transaksi penyimpanan / pemasukan tabungan, tombol untuk mencetak slip setoran, field halaman untuk entry halaman, tombol Go untuk menuju ke halaman yang dicari, tombol First untuk menuju ke data yang paling awal, tombol Previous untuk menuju ke data sebelumnya, tombol Next untuk menuju ke data selanjutnya, tombol Last untuk menuju ke data yang paling akhir, tombol $\mathrm{x}$ untuk menghapus data.

- Menu Transaksi penarikan: field Masukkan No. Rekening untuk entry pencarian dengan menggunakan nomor rekening penabung, tombol Search untuk mencari data nama penabung dan jumlah saldo tabungan, tombol Input Penarikan untuk meng-input penarikan tabungan, field Nama Anggota untuk entry nama penabung, field Jumlah untuk entry jumlah penarikan tabungan (Rp), field Tanggal untuk entry tanggal penarikan tabungan, tombol Simpan untuk menyimpan data, tombol Kembali untuk membatalkan penarikan, field halaman untuk entry halaman, tombol Go untuk menuju ke halaman yang dicari, tombol First untuk menuju ke data yang paling awal, tombol Previous untuk menuju ke data sebelumnya, tombol Next untuk menuju ke data selanjutnya, tombol Last untuk menuju ke data yang paling akhir, tombol untuk mencetak slip penarikan, tombol $\mathrm{x}$ untuk menghapus data.

- Menu Laporan : field Dari Tanggal untuk entry tanggal transaksi yang dimaksud, field Anggota untuk entry nama penabung dengan menggunakan scroll pilihan, tombol CETAK untuk mencetak Laporan Buku Besar, Laporan Transaksi Penyimpanan, Laporan Transaksi Penarikan dalam bentuk excel. Laporan tersebut dapat tercetak secara keseluruhan penabung atau masing masing penabung. Jika ingin rekap seluruh penabung, maka tidak perlu menginput di field Anggota dan atau 
field nama penabung, tetapi langsung mengklik tombol CETAK.

- Menu Saldo : field Masukkan No. Rekening untuk entry pencarian dengan menggunakan nomor rekening penabung, tombol Search untukmencari data Saldo penabung.

- Logout : untuk menutup sistem transaksi.

\section{HASIL DAN PEMBAHASAN}

Pada tahap selanjutnya, penulis mulai memasuki desain / perancangan sistem. Berikut kategori - kategori yang akan dirancang :

a. Proses pendaftaran: menginputkan data penabung seperti nomor rekening, NIK, nama, alamat, dan nomor telepon ke dalam sistem oleh petugas / admin.

b. Proses pemasukan Saldo Awal: berhubung sistem operasional pada bank sampah ini berkesinambungan secara terus menerus maka peneliti mendesain menu Saldo Awal untuk mengurangi tenaga, pikiran, dan waktu dalam penginputan penyimpanan dan penarikan tabungan dari awal periode bank sampah ini berdiri. Berdasarkan informasi dari inputan data penabung, petugas / admin menginput besar saldo awal penabung sampai dengan tanggal 31 Maret 2017 dan menginput tanggal tersebut ke dalam sistem.

c. Proses penyimpanan / pemasukan tabungan: berdasarkan informasi dari inputan data penabung, hasil pemilahan jenis sampah yang ditabung, jumlah sampah, berat sampah (kg), harga sampah, biaya jasa (\%), tanggal menabung, dan nomor nota diinput ke dalam sistem oleh petugas / admin. Total penyimpanan / pemasukan tabungan akan muncul disistem. Slip setoran dapat dicetak. d. Proses penarikan tabungan: berdasarkan informasi dari total penyimpanan / pemasukan tabungan, jika ada penabung yang akan mengambil tabungannya, petugas / admin menginput jumlah besaran penarikan tabungan dan tanggal penarikan dalam sistem. Slip penarikan dapat dicetak.

e. Proses penginputan ke dalam laporan Buku Besar: berdasarkan informasi dari inputan penyimpanan / pemasukan dan penarikan tabungan tersebut, secara otomatis menginput rekapan transaksi tabungan dan total hasil tabungan ke laporan Buku Besar dalam sistem. Laporan tersebut dapat dicetak secara rekap maupun masing-masing penabung dengan menginput tanggal transaksi yang diinginkan dan atau nama penabung.

f. Proses penginputan ke dalam menu Saldo : berdasarkan informasi dari laporan Buku Besar, secara otomatis menginput secara total besarnya tabungan ke menu Saldo yang dapat diinformasikan ke dalam web yang dapat diakses oleh penabung menggunakan password.

g. Proses pemasukan kas : pengepul membeli sampah yang telah terpilah dan bersih dari Bank Sampah Terpadu Mina Sembada dengan harga yang lebih tinggi dibanding sampah yang belum terpilah dan kotor pada umumnya. Hasil penjualan tersebut dikurangi total jumlah tabungan dari informasi menu Saldo yang telah dikurangi biaya operasional sebesar 15\% menjadi pemasukan kas Bank Sampah tersebut.

h. Proses pencarian data : berdasar dari data input-an pada waktu pendaftaran kemudian meng-input salah satu identitas penabung yang telah tersimpan dalam database yang akan melakukan transaksi menabung pada waktu berikutnya. 
Tabel 1. Tabel Hasil Pengujian Sistem Informasi Manajemen Transaksi Tabungan Bank Sampah Terpadu Mina Sembada






\subsection{Pengujian Pengguna}

Tahapan pengujian merupakan tahapan tambahan yang dilakukan untuk memastikan sistem telah bekerja dengan baik. Pengujian yang digunakan oleh penulis yaitu meliputi.

\subsubsection{Black Box Testing}

Menurut Tenia Wahyuningrum dan Dwi Januarita (2015), pengujian metode black box merupakan pengujian terhadap fungsionalitas input / output dari suatu perangkat lunak. Penguji mendefinisikan sekumpulan kondisi input kemudian melakukan sejumlah pengujian terhadap program sehingga menghasilkan suatu output yang nilainya dapat dievaluasi. Black box testing mencoba untuk menemukan kesalahan dalam kategori :

(a) Fungsi tidak benar atau hilang.

(b) Kesalahan interface atau antarmuka.

(c) Kesalahan dalam struktur data atau akses database eksternal.

(d) Kesalahan kinerja atau perilaku.

(e) Kesalahan inisialisasi dan terminasi.

Berdasarkan hasil pengujian di atas dapat ditarik kesimpulan bahwa perangkat lunak secara fungsional mengeluarkan hasil sesuai dengan yang diharapkan.

\subsubsection{Pengukuran Usability Dengan Use Questionnaire}

Menurut Ido dalam Dedi Rianto Rahadi (2014) terdapat beberapa aspek pengukuran usability yaitu efisiensi, efektivitas dan kepuasan. Menurut Jacob Nielsen dalam Dedi Rianto Rahadi (2014) usability adalah atribut kualitas yang menjelaskan atau mengukur seberapa mudah penggunaan suatu antar muka (interface).
Usability diukur dengan lima kriteria yaitu: learnability, efficiency, memorability, errors dan satisfaction. Learnability mengukur tingkat kemudahan melakukan tugas - tugas sederhana ketika pertama kali menemui suatu desain.

Efficiency mengukur kecepatan mengerjakan tugas tertentu setelah mempelajari desain tersebut. Memorability melihat seberapa cepat pengguna mendapatkan kembali kecakapan dalam menggunakan desain tersebut ketika kembali setelah beberapa waktu. Errors melihat seberapa banyak kesalahan yang dilakukan pengguna, separah apa kesalahan yang dibuat, dan semudah apa mereka mendapatkan penyelesaian. Satisfaction mengukur tingkat kepuasan dalam menggunakan desain.

Pengumpulan data dilakukan dengan menyebar kuesioner kepada petugas / admin dan penabung Bank Sampah Terpadu Mina Sembada menggunakan Skala Likert. Menurut Sugiyono (1999) dalam Dedi Rianto Rahadi (2014) Skala Likert digunakan untuk mengukur sikap, pendapat dan persepsi seseorang atau sekelompok orang tentang fenomena sosial yang merupakan skala kontinum bipolar, pada ujung sebelah kiri (angka rendah) menggambarkan suatu jawaban yang bersifat negatif. Sedang ujung sebelah kanan (angka tinggi) menggambarkan suatu jawaban yang bersifat positif. Data tentang dimensi dari variabel - variabel yang dianalisis dalam penelitian ini yang ditujukan kepada responden menggunakan skala $1 \mathrm{~s} / \mathrm{d} 5$ untuk mendapatkan data yang bersifat ordinal dan diberi skor terdapat pada tabel 2. 
Tabel 2. Score Nilai Kuesioner

\begin{tabular}{cccccc}
\hline PK & SS & S & CM & M & SM \\
\hline Nilai & 1 & 2 & 3 & 4 & 5 \\
\hline
\end{tabular}

\begin{tabular}{lll}
\hline \multicolumn{2}{l}{ Keterangan : } \\
\hline PK & $:$ Pertanyaan Kuesioner. \\
SS & $:$ & Sangat Sulit. \\
S & $:$ & Sulit. \\
CM & $:$ & Cukup Mudah. \\
M & $:$ & Mudah. \\
SM & $:$ & Sangat Mudah.
\end{tabular}

Tabel 3. Rekap Nilai Usability

\begin{tabular}{|c|c|c|}
\hline NO. & PERTANYAAN & NILAI \\
\hline \multicolumn{3}{|c|}{ ASPEK SISTEM (SYSTEM) } \\
\hline 1 & Apakah tampilan website mudah dikenali? & 4,04 \\
\hline 2 & Apakah website mudah dioperasikan? & 3,81 \\
\hline 3 & $\begin{array}{l}\text { Apakah tampilan warna pada website enak dilihat dan tidak } \\
\text { membosankan? }\end{array}$ & 3,88 \\
\hline \multicolumn{3}{|c|}{ ASPEK PENGGUNA (USER) } \\
\hline 4 & Apakah tampilan menu dalam website mudah dikenali? & 3,88 \\
\hline 5 & Apakah tampilan menu dalam website mudah dicari? & 3,81 \\
\hline 6 & Apakah tampilan menu dalam website mudah dibaca? & 3,92 \\
\hline 7 & Apakah aplikasi yang dibutuhkan mudah di download? & 3,58 \\
\hline 8 & Apakah simbol - simbol gambar mudah dipahami? & 3,65 \\
\hline \multicolumn{3}{|c|}{ ASPEK INTERAKSI (INTERACTION) } \\
\hline 9 & Apakah mudah mengakses informasi yang ditawarkan? & 3,77 \\
\hline 10 & $\begin{array}{l}\text { Apakah spesifikasi menu yang ditawarkan sesuai dengan } \\
\text { kebutuhan? }\end{array}$ & 3,60 \\
\hline 11 & $\begin{array}{l}\text { Apakah aplikasi transaksi penyimpanan tabungan penabung yang } \\
\text { tersedia mudah diakses? (khusus petugas / admin) }\end{array}$ & 4,33 \\
\hline 12 & $\begin{array}{l}\text { Apakah aplikasi transaksi penarikan tabungan penabung yang } \\
\text { tersedia mudah diakses? (khusus petugas / admin) }\end{array}$ & 4,33 \\
\hline 13 & $\begin{array}{l}\text { Apakah aplikasi saldo tabungan penabung yang tersedia mudah } \\
\text { diakses? }\end{array}$ & 3,71 \\
\hline 14 & Apakah menu dan tampilan halaman website mudah diingat? & 3,56 \\
\hline
\end{tabular}


Nilai rata - rata masing - masing responden dapat dikelompokkan dalam kelas interval. Ukuran interval berguna untuk memberikan informasi tentang interval, orang atau obyek - obyek yang lain. Jumlah kelas $=5$, sehingga intervalnya dapat dihitung menjadi :

$$
\begin{aligned}
\text { Interval } & =\frac{\text { Nilai Maksimal }- \text { Nilai Minimal }}{5} \\
& =\frac{5-1}{5}=0,8
\end{aligned}
$$

Dari informasi tersebut dapat ditentukan skala distribusi kriteria pendapat responden sebagai berikut :

a. Nilai jawaban $1,00 \mathrm{~s} / \mathrm{d} 1,79=$ desain sistem informasi manajemen transaksi tabungan berbasis web sangat sulit.

b. Nilai jawaban $1,80 \mathrm{~s} / \mathrm{d} 2,59=$ desain sistem informasi manajemen transaksi tabungan berbasis web sulit.

c. Nilai jawaban $2,60 \mathrm{~s} / \mathrm{d} 3,39=$ desain sistem informasi manajemen transaksi tabungan berbasis web cukup mudah.

d. Nilai jawaban $3,40 \mathrm{~s} / \mathrm{d} 4,19=$ desain sistem informasi manajemen transaksi tabungan berbasis web mudah.

e. Nilai jawaban $4,20 \mathrm{~s} / \mathrm{d} 5,00=$ desain sistem informasi manajemen transaksi tabungan berbasis web sangat mudah.

Populasi yang diambil dalam penelitian ini adalah seluruh petugas / admin dan penabung pada Bank Sampah Terpadu Mina Sembada sebanyak 120 orang.
Menurut Arikunto (2016 : 112) dalam Ninoy Yudhistya Sulistiyono (2013) "apabila subyeknya kurang dari seratus, lebih baik diambil semua sehingga penelitiannya merupakan populasi”. Tetapi, jika jumlah subjek besar, dapat diambil antara $10-15 \%$ atau $15-25 \%$ atau lebih". Dalam penelitian Ninoy Yudhistya Sulistiyono (2013), dari keseluruhan populasi semuanya berjumlah 114 orang, maka sesuai pendapat di atas jumlah sampel dalam penelitian tersebut dapat diambil $40 \%$ dari keseluruhan jumlah populasi. Sehingga didapat jumlah sampel untuk penelitian tersebut berjumlah 46 orang. Dari pendapat tersebut, maka peneliti dapat menentukan jumlah sampel dengan populasi sebanyak 120 orang anggota Bank Sampah Terpadu Mina Sembada yaitu sebanyak 48 orang.

Teknik sampling yang digunakan dalam penelitian ini adalah simple random sampling. Menurut Margono (2004:126) dalam Ahmad Dahlan (2016) menyatakan bahwa simple random sampling adalah teknik untuk mendapatkan sampel yang langsung dilakukan pada unit sampling. Dengan demikian setiap unit sampling sebagai unsur populasi yang terpencil memperoleh peluang yang sama untuk menjadi sampel atau untuk mewakili populasi. Cara demikian dilakukan bila anggota populasi dianggap homogen. Teknik ini dapat dipergunakan bilamana jumlah unit sampling dalam suatu populasi tidak terlalu besar. Setelah dilakukan penyebaran kuesioner, maka selanjutnya dilakukan rekap nilai usability terhadap hasil kuesioner yang telah disebar. 
Dari Tabel 3, apabila disesuaikan kembali hubungannya dengan masing masing aspek usability, dapat dikatakan bahwa perangkat lunak aplikasi website yang telah dibuat telah memiliki nilai usability, yaitu : learnability, Efficiency, Memorability, Errors, dan Satisfaction yang baik. Hal ini ditunjukkan dengan nilai hasil usability pada kelima atribut, sebagai berikut :

a. Nilai atribut "kemudahan interface website dikenali" sebesar 4,04 yang menunjukkan bahwa desain sistem informasi manajemen transaksi tabungan berbasis web ini telah memiliki nilai aspek Learnability yang mudah.

b. Nilai atribut "kemudahan website untuk dioperasikan" sebesar 3,81 menunjukkan bahwa desain sistem informasi transaksi tabungan berbasis web ini telah memiliki nilai aspek Efficiency yang mudah.

c. Nilai atribut "kemudahan mengingat kembali menu dan tampilan pada website" sebesar 3,56 menunjukkan bahwa desain sistem informasi transaksi tabungan berbasis web ini telah memiliki nilai aspek memorability yang mudah. d. Nilai atribut "kemudahan aplikasi website yang ada mudah dibaca" sebesar 3,92 dan atribut "simbol - simbol gambar mudah dipahami" sebesar 3,65 membuat desain sistem informasi transaksi tabungan berbasis web ini dapat dikatakan telah meminimalisasi aspek Errors.

e. Keseluruhan atribut yang memiliki nilai rata - rata sebesar 3,848 yang dibulatkan menjadi 3,85 menunjukkan jika desain sistem informasi transaksi tabungan berbasis web ini telah mempunyai aspek Satisfaction yang mudah.

\section{KESIMPULAN DAN SARAN}

\subsection{Kesimpulan}

Berdasarkan dari hasil penelitian, maka dapat ditarik kesimpulan sebagai berikut :

a. Sistem yang dirancang dapat mempercepat, memudahkan, dan meminimalisir kesalahan petugas / admin dalam mengelola transaksi tabungan dalam pengisian data, pencarian data, pengolahan data sampai dengan laporan yang berupa Buku Besar. Memudahkan juga bagi penabung dalam mengakses jumlah saldo yang telah tertabung di bank sampah ini. Bagi orang luar juga akan mudah mencari informasi terkait Bank Sampah Terpadu Mina Sembada. 
b. Hasil rekap nilai usability menunjukkan keseluruhan atribut memiliki nilai penerimaan usability oleh user rata rata dengan nilai pembulatan 3,85 sehingga dapat dikatakan bahwa desain sistem informasi manajemen transaksi tabungan berbasis web ini mudah dipelajari serta dimengerti oleh user.

c. Dengan adanya sistem informasi manajemen transaksi tabungan ini, selain bermanfaat untuk kesehatan masyarakat dengan adanya pemanfaatan sampah yang secara otomatis mengurangi timbunan sampah yang dapat mengganggu kesehatan masyarakat, dapat juga meningkatkan pendapatan masyarakat dengan menabung sampah yang notabene adalah barang yang tadinya tidak memiliki nilai ekonomis kemudian dengan adanya bank sampah menjadi barang yang bernilai guna, dan membantu pemerintah dalam menciptakan lingkungan yang bersih dan sehat karena mengurangi timbulan sampah mulai dari lingkungan terkecil. Kemudian menginformasikannya melalui website untuk menginformasikannya lagi ke lingkungan yang lebih luas, serta mengedukasi masyarakat dalam pemanfaatan sampah dan membuat masyakarat lebih mengenal teknologi.

\subsection{Saran}

Berdasarkan kesimpulan tersebut, dapat diusulkan saran untuk Bank Sampah Terpadu Mina Sembada yaitu petugas / admin hendaknya menggunakan sistem informasi ini untuk seterusnya dan ikut dalam meningkatkan serta memelihara penggunaannya agar sistem ini dapat selalu berjalan dengan efektif dan efisien. Selanjutnya, untuk aplikasi website dapat di upgrade dikemudian hari dengan menambahkan fitur interaksi / testimoni agar komunikasi dapat lebih aktif diantara petugas / admin dengan penabung maupun orang luar.

\section{DAFTAR PUSTAKA}

Dahlan, A., 2016. Definisi Sampling Serta Jenis Metode dan Teknik Sampling. Diakses pada tanggal 6 September 2017, dari website Eureka Pendidikan

http://www.eurekapendidikan.com/2 015/09/defenisi-sampling-danteknik-sampling.html.

Farabi, R. A., 2012. Sistem Informasi Pemesanan Tiket Angkutan Darat, Udara, dan Laut Berbasis Web (Studi Kasus Pada Bintang Tour dan Travel). D.I. Yogyakarta: FTI UII. 
Rahadi, D. R., 2014. Pengukuran Usability Sistem Menggunakan Use Questionnaire pada Aplikasi Android. Jurnal Sistem Informasi (JSI), 6 (1) :2355-4614.

Sulistiyono, N. Y., 2013. Gambaran Asupan Zat Gizi dan Aktifitas Fisik Mahasiswa Ilmu Keolahragaan. Diakses pada tanggal 6 September 2017, dari website repository. upi.edu

http://repository.upi.edu/203/6/S_P JKR_0802558_CHAPTER\%203. $p d f$.

Syafputri, E., 2012. Kelurahan Malaka Sari Jadi Percontohan Bank Sampah. Diakses pada tanggal 16 September 2017, dari website antaranews.com :

http://www.antaranews.com/berita/ 298230/kelurahan-malaka-sarijadi-percontohan-bank-sampah.

Wahyuningrum, T., Januarita, D., 2015. Implementasi dan Pengujian Web E-commerce untuk Produk Unggulan Desa. Jurnal Komputer Terapan, 1 ( 1) : 57-66. 